Physical education at preschools: practitioners' and children's engagements with physical activity and health discourses

Nollaig McEvilly ${ }^{a *}$, Martine Verheul ${ }^{\mathrm{b}}$ and Matthew Atencio ${ }^{\mathrm{c}}$

aDepartment of Sport and Exercise Sciences, University of Chester, UK; ' Institute for Sport, Physical Education and Health Sciences, The University of Edinburgh, UK; 'Department of Kinesiology, California State University, East Bay, USA

*Corresponding author. Department of Sport and Exercise Sciences, University of Chester, Parkgate Road, Chester, CH1 4BJ, UK. Email: n.mcevilly@chester.ac.uk 


\section{Physical education at preschools: practitioners' and children's engagements with physical activity and health discourses}

This paper focuses on one aspect of a qualitative study concerned with investigating the place and meaning of 'physical education' to practitioners and children at three preschools in Scotland. We examine the ways in which the participants engaged with discourses related to physical activity and health in order to construct their subjectivities. Fourteen practitioners and 70 children participated. Research methods employed were observations, interviews with adults, a group drawing and discussion activity with children, and interviews with children. Both the adults' and children's talk illustrated the dominance of neoliberal, healthism meanings which position individuals as responsible for their own health. While the children's talk primarily centred on health as a corporeal notion, the practitioners tended to talk about physical activity and health in both corporeal terms and in relation to the self more holistically. The practitioners also talked about physical activity as a means of regulating children's behaviour.

Keywords: physical education; preschool; discourses; healthism; neoliberalism.

\section{Introduction}

This paper reports on one element of a study concerned with investigating the place and meaning of 'physical education' to practitioners and children at three preschool ${ }^{1}$ contexts in Scotland. Underpinned by a poststructural theoretical framework, the study examined the discourses of physical education at the preschools, and interrogated the ways in which the participants engaged with these discourses in order to construct their subjectivities. Wright and Macdonald (2010) suggest that this type of research is needed to reveal diverse self-perceptions and identities in relation to particular experiences and discourses. In this paper, we examine the participants' differentiated engagements with discourses related to physical activity and health within the preschool physical education context.

1 Children in Scotland are entitled to free part-time preschool education from the term after their third birthdays. They usually move to primary school when aged four or five years (The City of Edinburgh Council, 2013). 
Our concern with preschool physical education relates to a change in the language associated with this subject in Scottish preschool curricular policy. While the previous preschool curriculum (Learning and Teaching Scotland (LTS) 2004) had a section entitled 'physical development and movement', the current curriculum Curriculum for Excellence (LTS 2009) - refers to 'physical education' in relation to preschool education. By focusing on preschool practitioners and children, our study allows us to explore why particular physical education discourses and practices may be supported or resisted in preschool contexts. Additionally, it allows us to investigate the effects of discourses that may otherwise be taken for granted and unquestioningly accepted (MacLure 2003).

\section{Background}

A poststructural theoretical framework views knowledge and its construction as value-laden and context-specific (Dahlberg, Moss, and Pence 2007). Such a perspective reveals how individuals are both subject to and subjects of power as they construct particular subjectivities (Grant 1997). A person's subjectivity, or sense of self, is constituted in relation to discourses, which are sets of truths that are (re)produced through power relations and social practices (Foucault 1973). A poststructural perspective is concerned with disrupting dominant discourses (Yelland and Kilderry 2008) in order to make 'visible what is usually hidden' (Rønholt 2002, 34) and thus scrutinise the potential 'work' of particular discourses.

\section{Neoliberal healthism discourse}

Much previous poststructural research in physical education, physical activity and health develops the concepts of self/subjectivity, power and discourse in the context 
of secondary school students or adults (e.g. O'Flynn and Petersen 2007; Wright, O’Flynn, and Macdonald 2006), while a smaller number of studies have involved primary school children (e.g. Burrows, Wright, and McCormack 2009; Macdonald et al. 2005). In the preschool domain, it appears that only O'Flynn (2012) has employed a poststructural perspective to analyse how health discourses constitute particular subjectivities and legitimise particular practices with regard to physical activity, food and bodies. We therefore aim to extend the aforementioned scholarship by similarly investigating the concepts of discourse, power and subjectivity in relation to preschool physical education. Such an investigation appears timely, given increasing societal concerns with health and obesity. In this context, schools, and particularly physical education lessons, are increasingly positioned as important sites for the promotion of healthy lifestyles (Cale and Harris 2013). McEvilly et al. (in press) highlight the increasing number of epidemiological studies seeking to increase physical activity participation amongst young children in order to prevent obesity and 'unhealthiness'; it seems that preschools are - or will be - similarly positioned as sites of intervention. This trend seems likely to manifest in Scotland, since the physical education curricular guidelines pertaining to children aged from three years old upwards are housed within the health and wellbeing subject area in Curriculum for Excellence.

A focus on promoting healthy lifestyles implies that individuals must change the way they live in order to achieve outcomes health authorities consider to be desirable (Gard 2008). This notion of individuals being responsible for their own health bears the hallmarks of neoliberalism. Macdonald $(2011,37)$ defines neoliberalism as 'an approach to governing society in such a way as to reconfigure people as productive economic entrepreneurs who are responsible for making sound 
choices in their education, work, health, and lifestyle'. Humans are considered to be rational, self-managing, autonomous individuals (Lupton 1999; Macdonald 2011). Consequently, people are deemed to be responsible for their own health through the work they do on themselves (Macdonald 2011). This notion of individuals being responsible for making 'healthy' lifestyle choices by, for example, avoiding 'bad' practices related to exercise and food, is known as healthism (Crawford 1980). Alignment with this discourse leads to the promotion of 'healthy lifestyles' at schools and specifically in physical education, where the notion that exercise equals fitness equals health (Gard and Wright 2001) is 'extolled, valorized and claimed as truth' (Johns 2005, 72).

\section{Poststructural critique of healthism}

However, a critical view suggests that obesity prevention and healthism discourses are only concerned with a 'scientifically normative view of health' (Quennerstedt 2008, 275). Practitioners are thus encouraged to surveil and classify children's bodies, in order to evaluate their size and weight. In this context, those who do not 'match' the criteria may be considered resistant, lazy, bad or weak (Johns 2005). The neoliberal, healthism concern with individual responsibility for health may perpetuate a 'blame the victim' culture, in which being fat is 'interpreted as an outward sign of neglect of one's corporeal self' (Evans 2003, 96). Such moral judgements may lead to certain children (and parents) being classified as ‘irresponsible and morally lacking' (Gard $2008,490)$. As such, healthism has the effect of obscuring the 'day-to-day realities of people's lives' (Gard and Wright 2005, 143) and pays no attention to the structural and environmental factors that constrain their abilities to make 'good' choices (Wright and Dean, 2007). Consequently, healthism stigmatises certain people (e.g. those from 
lower socio-economic groups) as 'at risk' and in need of intervention (Evans 2003; Gard and Wright 2005).

While health interventions may be 'uncritically welcomed as a kind of individual and cultural salvation' (Vander Schee and Boyles 2010, 170), their effects may not be benign (Evans 2003). We speculate whether preschool children may be positioned as 'couch potatoes' (Gard and Wright 2005) that must be controlled and monitored by expert adults, who subject them to biopedagogies (Harwood 2009). The concept of biopedagogies suggests that children in health promotion and obesity prevention contexts become subjected to disciplinary practices that aim to surveil, control and re-shape their bodies and their embodied selves. Burrows and Wright $(2004 ; 2007)$ suggest that, as well as encouraging adults to engage in surveillance and classification of children's bodies and practices, an emphasis on obesity discourses may lead children to engage in self-monitoring and self-surveillance regarding their bodies (e.g. their physical activity and eating practices). Brace-Govan (2002) employs the term 'bodywork' to describe these individualistic disciplinary bodily practices. Bodywork could lead to some children experiencing feelings of guilt, anxiety, fear and unhappiness (Burrows and Wright 2004; Evans 2003; Gard and Wright 2001). It seems that, in this context, while a health promotion agenda may have benevolent intentions, it could in fact be damaging to children's health and wellbeing (Evans 2003; Wright and Dean 2007).

We noted earlier that, while there is a paucity of preschool health and physical activity scholarship underpinned by poststructuralism, an emerging body of poststructural scholarship has focused on primary school children. Burrows, Wright, and Jungersen-Smith (2002) and Burrows, Wright, and McCormack (2009), for instance, investigated how children aged between eight and 13 talked about physical 
activity, fitness and health. They found that the children consistently mentioned 'good' eating practices, drinking water, engaging in physical activity, and keeping clean as ways to be healthy, thus positioning health as a corporeal notion. According to Burrows, Wright, and Jungersen-Smith (2002), the children closely related the notions of fitness, weight and appearance, while many of their comments connected fatness with laziness. These authors also report that some children talked about teasing and harassment resulting from being perceived as overweight. Furthermore, Burrows's (2011) study involving children from indigenous and/or lower socioeconomic group backgrounds, found that one child talked about being teased for having 'a fat bottom' (346), while another spoke of his fear that he and members of his family had gained weight. A girl expressed confusion about being teased at school for having a fat body while, in her Samoan culture, her cousin got ridiculed for being thin. While Burrows notes that the children 'flip-flopped' between embracing and challenging normative healthism discourses, her study showed that they engaged with health messages in complex ways, demonstrating that they were 'neither cultural dopes nor dupes' (349).

The studies discussed illustrate how young children can share their thoughts and experiences in powerful and complex ways. The children in these studies engaged with discourses related to health and physical activity in diverse ways, demonstrating that they were not simply 'docile' bodies (Foucault 1991). Our study draws on Foucault's concept of technologies of the self $(1992 ; 2000)$ in order to investigate how children and practitioners at three preschools in Scotland engage with discourses related to physical activity and health. This means that we conceptualise individuals as actively involved in constituting their subjectivities (Foucault 2000) by choosing to invest in certain discourses over others. This approach allows us to understand the 
participants not merely as 'receptors of or the effects of discourse, but as desiring subjects involved in their own self-constitution' (O'Flynn 2004, 11, emphasis in original).

\section{Methodology}

The study was approved by the ethics committee of The Moray House School of Education, The University of Edinburgh. We employed a poststructural type of discourse analysis concerned with examining patterns in language (Wright 2004). Fieldwork was conducted by the lead author from March 2010 until January 2011. The preschools, which we refer to by the pseudonyms of Oakdale, Cheery Faces and Sunnyland, were purposefully selected and differed in terms of size and socioeconomic status (SES) (see Table 1).

'Insert Table 1 here'

The lead author engaged in participant observation and held interviews with practitioners and children. Fourteen adults and 70 children (aged three to five years) participated; pseudonyms are used to protect their anonymity. With the exception of Sarah and Rachel at Cheery Faces, who each participated in one interview, the adults participated in three interviews each. Most adult interviews featured one participant, but four practitioners asked to be interviewed in pairs. Some children (22) were observed only, while 48 participated in group mind-mapping and/or interviews. Group mind-mapping involved children sitting in groups around a piece of paper, on which they drew pictures related to, and talked about, what they did during 'physical education'. Children's interviews were informal, and featured resources including 
photographs, colouring sheets, opportunities to draw, a picture card sorting activity and a teddy bear. We believed that as well as seeking parental consent regarding the children's participation, it was important to seek assent from the children themselves (Gallagher 2010). Throughout the study, children were asked if they were happy to participate in group mind-mapping and interviews. The number of interviews they participated in varied, mainly because of their willingness to participate. Duration of interviews also differed, although they generally lasted between ten and 20 minutes.

Interviews and group mind-mapping sessions were transcribed and interpreted as discursive texts, as were the field-notes. Drawing on guidelines proposed by MacLure (2003), we devised analytical questions to interrogate the data. The analysis reported in this paper probes around the following questions: (1) what 'truths' and meanings related to physical activity and health do the participants construct and privilege? (2) how are knowledge claims related to physical activity and health established and defended? and (3) what are possible consequences regarding practitioners' and children's practices and subjectivities? We subjected the texts to repeated 'close reading' (Burrows 2010, 239) in order to answer these analytical questions.

Findings and discussion

Adults' talk about physical activity and health in the preschool context

Many of the practitioners spoke about 'physical education' in ways that reflected Curriculum for Excellence's foregrounding of physical activity and health discourses. For instance, some of them - Amanda (Oakdale), Jean (Sunnyland), Jessica (Sunnyland) and Sarah (Cheery Faces) in particular - positioned physical 
activity as important in relation to physical health and obesity prevention. Sarah, for example, when asked about the focus of preschool 'physical education' at Cheery Faces, initially talked about motor skill development, but then said:

...I think it's also important as well because there's such a big focus just now all about obesity in children as well and, you know, you can see the children that are already starting to get lazy at this age because they haven't been pushed to do the sort of...not pushed - that's not the right word - but, like, encouraged, or haven't enjoyed something that they've done and that's put them off. (Sarah, Cheery Faces)

Sarah's talk appeared to reflect Curriculum for Excellence's concern with encouraging children to be physically active in order to prevent obesity. She revealed her investment in these physical activity and health discourses by referring to children who are 'already starting to get lazy at this age'; by making this moral judgement about particular children (Gard 2008), Sarah implied that obesity is preventable through choosing to engage in certain practices. By positioning laziness as the cause of obesity, she conjured up images of 'couch potatoes', thus characterising obesity as a 'story of sloth and gluttony' (Gard and Wright 2005, 6). Sarah characterised physical activity as a means of working on children's bodies in order to prevent obesity.

Jean (Sunnyland) similarly positioned physical activity as a means of preventing overweight and obesity. She revealed that she engaged in surveillance of children's bodies by referring to a child who was 'overweight': 
...we've got one little boy that's a little bit chubby, should one say, and you see him and he's trying and he does, but he's just not got the same get up and go as the other children, who really their weight is correct, you know?

Whereas you can tell he's just a little bit overweight - well, not a little bit, quite a bit - and his parents are trying to do something about it, but it's unfortunate he likes to drink anything that's got sugar in it, you know? So... but we've been at the hospital and we've got the...you know, we're working through that as well, but you can see the difference with somebody that can just pick themselves up and run and some of them are very, very quick. (Jean, Sunnyland)

Jean drew on the healthism discourse to characterise the boy's overweight as the result of a lack of 'get up and go' combined with overindulgence on sugary drinks. Jean compared the boy's 'bad' practices to those of other children, whose weight she deemed to be 'correct' and who she said were more motivated to run around. In contrast to the 'overweight' boy, these other children were therefore positioned as 'good' subjects of neoliberal and healthism discourses. Although the boy 'tried' to be active, he was seen to be in need of medical intervention and thus salvation (Vander Schee and Boyles 2010).

Amanda (Oakdale) was another practitioner who positioned physical activity as a means of working on children's bodies in order to prevent 'unhealthiness'; she too bought into what Foucault (1992) calls the mode of subjection - the rules and 'truths' - associated with healthism. While Amanda engaged with the notion of physical activity in different ways when talking about why it was important for the children at Oakdale, she primarily constructed it as significant in relation to their 
health; she stated that it was important because 'there's lots of children in this school who eat appallingly and don't exercise'. She emphasised that she wanted the children to enjoy physical education so they would continue to participate in it and thus 'avoid' issues like obesity. According to Amanda, the staff at Oakdale considered teaching the children about health to be an important aspect of their jobs. She explained that because the school is located in an area deemed to be of low SES, it was important for teachers to take responsibility for educating children about health, as many of them were unlikely to learn about it outside of school. Her talk supported Vander Schee and Boyles's (2010) contention that health interventions are often uncritically viewed as 'necessary' forms of salvation. Atencio (2010) further argues that young people from lower socioeconomic groups are often specifically targeted by health interventions without taking into account their unique social, cultural and personal needs and histories.

Amanda's engagement in 'othering' revealed how strongly she was invested in healthism. O'Flynn (2004) explains that 'othering' involves an individual referring to the practices of other people in order to differentiate and classify his or her own practices. 'Othering' was evident in Amanda's contrasting of the 'positive role models' children encounter at school (i.e. teachers including herself) with either absent or negative role models outside of school (i.e. parents, family members and others in the community). Her 'othering' had the effect of positioning her own practices in relation to children's health as 'better' than those of people the children encountered outside school. When talking specifically about preschool children, however, Amanda spoke about the importance of not pushing 'healthy eating' messages too strongly, as she said it was important not to have children 'worrying about eating bad things when they're three'. This latter perspective illustrates how 
discourses such as healthism work to produce compliance as well as contradictory beliefs and practices.

Like Amanda, Jean (Sunnyland) talked in terms of 'intervening' or 'taking responsibility' for children's physical activity. She repeatedly mentioned that because many children attending Sunnyland lived in city centre flats, they spent long periods indoors and so it was crucial to provide them with opportunities for physical activity. Jean talked about parents being too tired or busy to engage in physical activity with their children. She therefore chose to provide children with opportunities for physical activity at Sunnyland as she characterised it as something they 'needed' to experience.

Jean maintained that there was a greater emphasis on informing children about healthy eating nowadays than there had been in the past. She noted that five years ago, she would not have been so concerned about it. When asked why this was, she implied that it related to panics about the so-called 'obesity epidemic':

I think it's because of the hype in the media and everything as well. It's brought you, made you more aware. I think I'm actually healthier; I eat better than I did years back and I do think it does help everybody. (Jean, Sunnyland)

Again, Jean acted in accordance with the moral code of healthism, revealing that she bought into its mode of subjection (Foucault 1992) regarding 'healthy' eating practices. Although she used the word 'hype', she did not use it in a negative or critical sense; rather, media 'hype' about 'bad' eating practices has been a positive thing that has 'informed' people (herself included) and consequently 'helped' them become healthier by choosing to engage in 'better' eating practices. 
Jean engaged more critically with this emphasis on 'healthy eating', however, when talking about a Care Commission ${ }^{2}$ inspection. She stated that an inspector visited Sunnyland on the day of the children's Halloween party and criticised the practitioners for providing children with 'unhealthy' food including cake and crisps. Jean expressed frustration about the inspector's criticism, showing that she did not align with healthism to the point that 'bad' foods should be eliminated altogether. Similar to the young women in Atencio's (2010) study of multi-ethnic young people's engagements with health discourses, Jean positioned 'unhealthy' foods such as cakes and crisps as treats that could be a source of pleasure.

The practitioners' discussions about encouraging children to be active and educating them about health positioned the preschools as appropriate sites for promoting healthy lifestyles. This aligns with the contention of Cale and Harris (2013) that schools, and physical education contexts in particular, are increasingly positioned as important sites for health promotion. Although some of the women appeared to recognise that structural factors including social issues and inequalities can impact on children's health, their overriding message was that 'education' about health and wellbeing would enable children to lead healthy lives. We suggest, however, that the simplistic construction of education about health and wellbeing as the key to a healthy life can ignore the 'day-to-day realities of people's lives' (Gard and Wright 2005, 143) and obscure the structural and environmental factors that constrain their abilities to make 'good' choices (Wright and Dean 2007).

Furthermore, analysis of the women's talk showed how the preschools made particular meanings, discourses, practices and ultimately subjectivities available to the participants. The settings were therefore implicated in the production of the its work passed to a new body, Social Care and Social Work Improvement Scotland (SCSWIS). 
participants' subjectivities (O'Flynn 2004). Amanda's talk showed that there was a major emphasis on staff 'taking responsibility' for children's health at Oakdale, as the children there were considered to be particularly 'at risk' because of their 'disadvantaged' backgrounds. Amanda therefore positioned the children at Oakdale as 'deficient, disadvantaged and in need of intervention' (O'Flynn 2010, 433). Her talk supported Evans and Rich's $(2011,366)$ suggestion that discourses and practices concerned with obesity prevention are a contemporary version of the child-saving movement, because of their intention "to rescue a child population "at risk" not just from bad health but bad parents and family inadequacies that are deemed to produce it'. While Jean similarly positioned some children at Sunnyland as in need of 'salvation', it is notable that the practitioners at Cheery Faces - which is located in a suburban, 'middle class' area - did not position children in this way. None of the practitioners at Cheery Faces talked in terms of the children needing 'rescuing' from 'problematic' and 'risky' family lives (O'Flynn 2004).

Some practitioners positioned physical activity as important for health and wellbeing more widely than just in terms of physical health. The chance to get fresh air and run around was something the practitioners at Sunnyland in particular spoke about. Ivy, for instance, talked about both children and adults experiencing a 'rush' when engaging in physical activity. She positioned the indoor space as restrictive and 'confined', where children had little option but to be sedentary. She characterised the chance to go outside and run around as imperative for both children and adults, in order for them to feel uplifted. Vanessa and Serena similarly talked about both children and adults feeling 'cooped up' to the point that 'you're tearing your hair out' (Vanessa, Cheery Faces) and 'just need to go outside' (Serena, Cheery Faces). 
Another way the practitioners talked about physical activity was in terms of regulating children's behaviour. The comments above by Ivy, Serena and Vanessa pertaining to children being 'cooped up' and 'needing' to run around relate to this theme. Vanessa and Serena were in agreement that physical activity was important because 'it lets off steam' (Vanessa, Cheery Faces). They talked about children's opportunities for physical activity as a means of counteracting what they regarded as misbehaviour. Ironically, this 'misbehaviour' seemed to involve physical activity; Serena and Vanessa described it in terms of children being full of energy, 'desperate to run around', 'wild' (Vanessa, Cheery Faces) and 'crazy' (Serena, Cheery Faces). The two women therefore constructed 'physical activity' as something that needed to be regulated and limited; 'physical activity' should only take place at particular times and in particular places.

Many other practitioners - including Ivy, Jean, Jessica, Naomi, Stacey, Alison and Dawn - similarly talked about the importance of physical activity for giving children a chance to 'let off steam' so they would not be badly behaved as a result of having 'excess energy' (Ivy, Sunnyland). They therefore talked about the 'energyin/energy-out' balance (Gard and Wright 2005, 38) not just in relation to weight and health, but in terms of children's behaviour. The chance to engage in physical activity was constructed not just as important in terms of children's health, but as a device which 'calms them, takes the energy out of them' (Naomi, Sunnyland). Jean (Sunnyland) explained that 'letting off steam' helped children concentrate. She positioned physical activity as important in relation to learning - not in terms of physical education, but as a vehicle for aiding 'classroom' learning. She characterised energy as something negative, in that it restricted children's abilities to concentrate and consequently made practitioners' jobs more difficult. Opportunities for physical 
activity were thus a technique of regulation; children were easier to 'manage' after using up some energy. As such, it seemed that sometimes the practitioners chose to provide children with opportunities for physical activity in order to make their jobs easier. Thus, on some occasions, children's opportunities for physical activity may have been more for the adults' benefit than the children's.

\section{Children's talk about physical activity and health}

Similar to the participants in Burrows, Wright, and Jungersen-Smith's (2002) and Burrows, Wright, and McCormack's (2009) studies, the children primarily positioned health in corporeal terms, and regularly talked about 'good' eating practices. Indeed, food was the first thing many children mentioned when asked about health. Their responses when asked if they ever did anything at nursery to help them be healthy included:

Fruit is always healthy. (Colin, Oakdale)

Like eat vegetables. [...] 'Cause it's...'cause it's got vitamin C in it. (Michelle, Cheery Faces)

Mmm...lunch. [...] Or breakfast makes you healthy. (Laurel, Sunnyland)

Eat snack. [...] But mostly when it's not chocolate! [Laughs] (Oscar, Sunnyland) 
These quotes show that the children were aware of the healthism message that positions certain foods as 'good' (e.g. fruit, vegetables) and others as 'bad' (e.g. chocolate). Michelle even 'proves' that eating vegetables is important by drawing on a medical or scientific discourse related to their 'vitamin C' content. Atencio (2010) has similarly noted that young people come to speak about health in these categorical ways; he suggests that this type of dichotomous health talk is often easily offered by young people in direct relation to the healthism discourse.

As well as talking about 'healthy' eating practices, many children referred to physical activity when asked about health. Some talked about physical activity in terms of exercise and fitness. For instance, when Russell, during a mind-mapping session at Oakdale, stated that he exercised during physical education, Ashleigh explained that exercise meant working on becoming fit. The lead author asked her to elaborate:

NOLLAIG: What does 'fit' mean?

ASHLEIGH: It means we have to do loads of running and jogging.

$[\ldots]$

ASHLEIGH: Running and jogging.

NOLLAIG: 'Running and jogging'. And do you like running and jogging, Ashleigh?

ASHLEIGH: Yeah.

NOLLAIG: Really? Yeah? Anything else you like doing? Any other activities?

ASHLEIGH: I like to eat fruit so I can keep healthy. 
NOLLAIG: Oh that's a great one - you like to eat fruit so you can keep healthy. Who knows what that means, 'healthy'?

ASHLEIGH: It means to keep very...it's to mean keep...it's to mean don't eat bad food or bad food will make you not...or bad food will make you ill, so you must eat good food, so then it won't make you ill.

(Ashleigh, Oakdale)

Ashleigh connected the notions of exercise, fitness, physical activity and health. Having referred to exercise in terms of getting fit, she talked about fitness in terms of physical activity. By saying 'we have to', she positioned fitness and physical activity as necessary. Ashleigh then created a binary between 'bad food' and 'good food', explaining that 'bad food' could make her ill. She thus positioned health as 'not being ill'. By positioning 'good' eating and physical activity practices as a means of working on her body in order to prevent illness, Ashleigh displayed awareness of the mode of subjection and ethical work (Foucault 1992) associated with healthism.

Perhaps reflecting the emphasis on health interventions at Oakdale that Amanda talked about, 'exercise' and 'fitness' were concepts many children there talked about. Numerous children at the other settings also engaged with these notions. For instance, Tristan (Sunnyland) regularly talked about exercise and fitness. He spoke about running around so he could get fit, explaining that in order to get fit he had to 'practise' running. He thus appeared to position fitness as something that had to be worked at. He also positioned getting fit as 'necessary' ('you have to').

When asked about things they did at nursery to help them to be healthy, the vast majority of the children's responses related to healthy eating and physical 
activity. There were a small number of responses referring to different practices. For instance, Joanna and Colin (both Oakdale) talked about the importance of getting sleep, Elle (Oakdale) mentioned washing her hands, and Bill (Cheery Faces), Tristan (Sunnyland) and Laurel (Sunnyland) talked about looking after their teeth. In all of the children's responses, only two did not relate to health as a corporeal notion: Elle (Oakdale) spoke about sharing, while Erin (Oakdale) mentioned helping her friends tidy up. Since all other responses positioned health in corporeal terms, the ethical substance (Foucault 1992) - the part of the self to be worked on - of the majority of the 'healthy' practices the children spoke about was the body. Abbie and Jane (Sunnyland), for instance, when asked if they did anything at nursery to help them to be healthy, spoke initially about the importance of eating fruit and lunch, and went on to provide numerous other suggestions that similarly focused on physical health:

ABBIE: $\quad$ But the most important thing is to never touch a crocodile.

NOLLAIG: That's the most important thing to stay healthy - never touch a crocodile?

ABBIE: $\quad$ No, 'cause...'cause if you touch a crocodile, it will...

JANE: It will just bite your thumb.

ABBIE: $\quad$ 'Cause it will eat you up.

$[\ldots]$

NOLLAIG: And so is there anything else you can do to be healthy?

$[\ldots]$

NOLLAIG: Can you think of anything, Abbie or Jane?

ABBIE: $\quad$ To never get sunburnt. You can put...

NOLLAIG: That's a very good one actually, to never get sunburnt. 
ABBIE: $\quad$ 'Cause...'cause there's...

JANE: $\quad$ Don't stay close to the fire.

ABBIE: $\quad$ 'Cause if you...'cause...'cause...'cause if you get sunburnt, it will hurt you then.

NOLLAIG: That's right, and Jane said as well to never stay close to fire as well. Very good.

ABBIE: $\quad$ Fire's the most important thing not to touch.

NOLLAIG: Anything else to help you stay healthy?

ABBIE: $\quad$ To not...to not...

JANE: $\quad$ Stay $\ldots$

ABBIE: $\quad$ To not go across the road when a car is coming.

(Abbie and Jane, Sunnyland)

Abbie and Jane positioned health as 'absence of injury', characterising health as something that can be achieved by avoiding 'dangerous' practices such as getting sunburnt and getting hit by a car. By positioning health as achievable through avoidance of 'bad' practices (Crawford 1980), Abbie and Jane foregrounded the notion of individual responsibility and displayed awareness of the mode of subjection and ethical work (Foucault 1992) associated with neoliberal discourses related to avoiding risk (Evans and Davies 2004).

The children also talked about the effects of exercise in corporeal terms, thus positioning it as a means of working on their bodies. For instance, regarding exercise, Colin (Oakdale) and Michelle (Cheery Faces) talked about building strength, Ian (Cheery Faces) mentioned getting sweaty, Jane (Sunnyland) referred to being 
energised, and Abbie (Sunnyland) mentioned tiredness. Similarly, for Dan and David (Cheery Faces), 'good' health was not just avoidance of 'bad' health, and rather than listing many ways of 'being healthy', the ethical work (Foucault 1992) the two boys primarily talked about was physical activity. Throughout their interviews, they repeatedly talked about 'healthy bones' when asked about health, exercise and fitness. They defined being healthy as being 'fit' and having strong, 'energetic' bones that do not 'wobble'. David talked about vigorous exercise boosting energy levels:

...when the bones are tired when you're going slow and the bones are tired, then when you...when you run and then when you're on the tractor and sometimes when you run, your bones get...get...your bones...your bones get energy. (David, Cheery Faces)

Both Dan and David positioned physical activity as a means of working on the body in order to boost energy and 'healthiness'. Health was thus positioned in terms of physical strength and performance, while physical activity was characterised as the means of working on the body in order to achieve these 'benefits'.

Abbie (Sunnyland) was the only child to explicitly talk about physical activity in terms of avoidance of overweight and obesity. For her, physical activity was important in terms of preventing weight gain:

NOLLAIG: Do you think it's important to run around?

ABBIE: Well, yes.

NOLLAIG: It is? 
ABBIE: $\quad$ 'Cause if you don't run around...'cause run arounding is sporting and if you don't do sporting, your tummy will get fat. [Puts her arms in front of her tummy, as if it is very big]

NOLLAIG: Oh right, so to run around is to be sporty and if you don't do sports, your tummy will get fat? And you're showing me, you're moving your arm out like that. So did somebody tell you that? Who told you that?

ABBIE: $\quad$ My dad.

NOLLAIG: Your daddy?

ABBIE: $\quad$ And my mum.

NOLLAIG: And your mummy? Oh right, okay. And so do you...do you like doing sporty things then?

\section{[Abbie nods]}

NOLLAIG: Yeah? You're nodding.

ABBIE: $\quad$ 'Cause I don't...I don't want to get fat.

(Abbie, Sunnyland)

In a later interview, Abbie again said, 'if you don't do sport, you get fatter and fatter and fatter'. By connecting the notions of physical activity and weight, Abbie - at four years of age - positioned physical activity as a means of working on her body. It appeared that, for Abbie, the telos (Foucault 1992) or goal of this discourse and its associated practices was not to be overweight. She positioned the 'fat' body as 'other' in relation to the physically active, 'sporty' body. Her talk indicated that she may have been fearful of fat (Burrows and Wright 2007). Her characterisation of overweight 
and obesity as the result of a lack of physical activity illustrated her alignment with healthism. Abbie's contention that she gleaned this 'knowledge' about avoiding weight gain from her parents shows that healthism operates throughout society, rather than just in educational contexts.

Abbie also drew on healthism by connecting weight gain with 'bad' eating practices. When asked if she thought it was important to do things to be healthy, she said:

...yes, 'cause...'cause if you don't eat fruit and you just eat sweeties every day, your tummy will get fatter, fatter, fatter, fatter and then it's not good. [...] So you need to buy fruit. (Abbie, Sunnyland)

Like many other children, Abbie positioned eating 'good' food such as fruit as essential for being healthy. Unlike the other children, however, Abbie conceptualised being healthy as 'not being fat'.

While Abbie was the only child to explicitly talk about physical activity in terms of avoidance of overweight and obesity, Joanna (Oakdale) appeared to indirectly refer to these issues when explaining that 'fit and healthy' meant 'you can stay healthy and not be greedy'. Joanna characterised greed as incompatible with 'good' health, apparently linking 'bad' health with moral failings (Evans 2003; Gard and Wright 2005). She thus seemed to imply that good health is achievable through avoidance of 'bad' practices (Crawford 1980); she therefore appeared to draw on the healthism discourse.

The general absence of references to weight in the children's talk could perhaps be because other practitioners agreed with the view of Amanda who, as noted, 
expressed caution about overemphasising 'healthy' food messages to preschool children. Perhaps other preschool practitioners are similarly wary about talking directly to children about why they are being encouraged to 'eat fruit' and 'be active'. While practitioners' intentions may be preventing childhood overweight and obesity, perhaps they prefer to talk to the children in more generic terms about certain foods and physical activity being important for good health, without really explaining why. This could explain why some children, when asked what terms like exercise, health and fitness meant, repeated these terms in a circular fashion. It seemed that many of them were familiar with these words, but struggled to explain what they meant.

It is important to note, however, that some children displayed resistance to healthism. Thus, while they may have 'known' the rhetoric about 'good' eating and physical activity practices, they also showed that they were not simply assimilating discourse in a straightforward manner; they engaged with these notions more critically and in complex ways (Wright and Macdonald 2010). For instance, Abbie and Jane (Sunnyland) did not align with healthism to the point that 'bad' foods should be eliminated altogether; they agreed it was okay to occasionally have a small number of sweets as a treat. Furthermore, despite Abbie's repeated mentions of weight, she showed resistance to practices associated with healthism in her talk about physical activity. Despite her emphasis on its importance - and her numerous assertions that it was enjoyable - in three separate interviews, she complained that physical activity made her tired. Thus, for Abbie, physical activity, while 'important', was not always 'good'.

Dan (Cheery Faces) similarly explained he sometimes liked doing an adult-led physical activity called the space bubble activity, but that other times he did not like it. When asked if he enjoyed this particular activity, he stated, 'Yeah, but we always 
do them'. He implied that overemphasis on a specific type of physical activity could lead to boredom, by explaining that 'we always have them [space bubble activities] and that's why I don't like them every time...but I do like them when they're not every day'. Dan showed that he could engage with discourses in a complex way; rather than simplistically positioning himself as either 'for' or 'against' the space bubble activity, he talked in terms of seeing both the 'good' and 'bad' in it.

\section{Conclusion}

Our aim was to examine the ways in which preschool practitioners and children engaged with discourses related to physical activity and health. Both the adults' and children's talk illustrated the dominance of neoliberal, healthism meanings which position individuals as responsible for their own health through engagement in 'healthy' practices such as those related to eating and physical activity. Previous studies with children (e.g. Burrows, Wright, and McCormack 2009), young people (e.g. Atencio 2010) and primary school staff (e.g. Vander Schee 2009) have reported similar findings. While the adults in our study tended to talk about physical activity and health in both corporeal terms and in relation to the self more holistically, the children were primarily concerned with physical health. Again, this is similar to how the children in Burrows, Wright, and Jungersen-Smith's (2002) and Burrows, Wright, and McCormack's (2009) studies talked about health. However, in contrast to previous studies by Burrows (2010) and Macdonald et al. (2005), the children in the current study - with the exception of Abbie - tended not to talk about food and physical activity in relation to weight. However, although Abbie was the only child to explicitly express concern about gaining weight, her talk illustrated that preschoolers, like other young people, may experience feelings such as fear, worry and unhappiness 
because of concerns about their weight (Burrows and Wright 2004; Evans 2003; Gard and Wright 2001). Furthermore, her talk indicated that an emphasis on obesity discourses can lead preschool children to engage in self-monitoring and selfsurveillance regarding their bodies (Burrows and Wright 2004; 2007).

Wright and Macdonald (2010) argue that poststructural research can reveal people's complex and situated experiences and beliefs; they posit that this approach diverges from 'simplistic and universalized deficit' (8) narratives of children and young people making poor health choices due to inadequate knowledge or deliberate indifference - a perspective which can imbue feelings of guilt and anxiety. We accordingly hope that this paper has illustrated how important it is for researchers, policy-makers and practitioners to evaluate and critically reflect on the potential workings of discourses they privilege and take for granted. Our analysis has shown, for instance, that, as a result of their investment in healthism, practitioners in this study engaged in surveillance and classification of children's bodies. Furthermore, a four-year-old participant expressed concern about becoming overweight. We ask: do we want preschool children to feel this way? Do we want them to feel compelled to engage in disciplinary bodily practices such as self-monitoring and self-surveillance (Burrows and Wright 2004)? Are we even aware that our preschool practices can have these effects? We suggest that there is a need for practitioners to encourage children to engage more critically with notions such as health, physical activity and exercise, which of course practitioners would initially have to do themselves. One suggestion would be for practitioners to emphasise the importance of acceptance of diversity in terms of body size and shape. Another would be to encourage children to think about why some people may not be able to participate in physical activity. Furthermore, speaking with less certainty about connections between physical activity, food and 
health may help children learn that these issues are not simply about 'good' and 'bad' practices and therefore 'good' and 'bad' people.

This paper points to the need for future research to further probe preschool children's engagements with discourses related to physical activity and health. Further research is needed to examine how these discourses play out in complex ways through the lives, practices and subjectivity formation of preschool children and practitioners. We argue, following Wright and Macdonald (2010), that this type of research, grounded in poststructural theory, can further reveal how practitioners and children engage with health and physical activity based on their social, cultural, economic and personal backgrounds, with consequences for their everyday lives and life opportunities.

\section{Acknowledgements}

We would like to express sincere thanks to the practitioners and children at Oakdale, Cheery Faces and Sunnyland. Thanks too to Dr. Mike Jess and the Developmental Physical Education Group at The University of Edinburgh for funding the research. Finally, thanks to the anonymous reviewers for their feedback and advice on an earlier draft of this paper. 


\section{References}

Atencio, M. 2010. The Life Activity Project in the American Inner City: Multi-ethnic Young People's Engagements with Health Discourses. In Young People, Physical Activity and the Everyday, edited by J. Wright and D. Macdonald, 150-161. Abingdon: Routledge.

Brace-Govan, J. 2002. Looking at Bodywork: Women and Three Physical Activities. Journal of Sport \& Social Issues 26 (4): 403-420.

Burrows, L. 2010. 'Kiwi kids are Weet-Bix ${ }^{\mathrm{TM}}$ kids' - Body Matters in Childhood. Sport, Education and Society 15 (2): 235-251.

Burrows, L. 2011. 'I'm proud to be me': Health, Community and Schooling. Policy Futures in Education 9 (3): 341-352.

Burrows, L., and J. Wright. 2004. The Discursive Production of Childhood, Identity and Health. In Body Knowledge and Control: Studies in the Sociology of Physical Education and Health, edited by J. Evans, B. Davies and J. Wright, 83-95. London: Routledge.

Burrows, L., and J. Wright. 2007. Prescribing Practices: Shaping Healthy Children in Schools. International Journal of Children's Rights 15: 83-98.

Burrows, L., J. Wright, and J. Jungersen-Smith. 2002. "Measure your belly.” New Zealand Children's Constructions of Health and Fitness. Journal of Teaching in Physical Education 22: 39-48.

Burrows, L., J. Wright, and J. McCormack. 2009. Dosing Up on Food and Physical Activity: New Zealand Children's Ideas about 'Health'. Health Education Journal 68 (3): 157-169.

Cale, L., and J. Harris. 2013. 'Every Child (of Every Size) Matters' in Physical Education! Physical Education's Role in Childhood Obesity. Sport, Education and Society 18 (4): 433-452.

Crawford, R. 1980. Healthism and the Medicalization of Everyday Life. International Journal of Health Services 10 (3): 365-388.

Dahlberg, G., P. Moss, and A. Pence. 2007. Beyond Quality in Early Childhood Education and Care: Languages of Evaluation. Abingdon: Routledge.

Evans, J. 2003. Physical Education and Health: A Polemic or 'Let Them Eat Cake!' European Physical Education Review 9 (1): 87-101.

Evans, J., and B. Davies. 2004. Sociology, the Body and Health in a Risk Society. In Body Knowledge and Control: Studies in the Sociology of Physical Education and Health, edited by J. Evans, B. Davies and J. Wright, 35-51. London: Routledge.

Evans, J., and E. Rich. 2011. Body Policies and Body Pedagogies: Every Child Matters in Totally Pedagogised Schools? Journal of Education Policy 26 (3): 361-379.

Foucault, M. 1973. The Birth of the Clinic: An Archaeology of Medical Perception. London: Tavistock.

Foucault, M. 1991. Discipline and Punish: The Birth of the Prison. London: Penguin Books Ltd.

Foucault, M. 1992. The History of Sexuality, Volume 2: The Use of Pleasure. London: Penguin Books Ltd.

Foucault, M. 2000. Technologies of the Self. In Michel Foucault: Ethics, Subjectivity and Truth: Essential Works of Foucault 1954-1984, Volume 1, edited by P. Rabinow, 223-251. London: Penguin Books Ltd. 
Gallagher, M. 2010. Ethics. In Researching with Children and Young People: Research Design, Methods and Analysis, edited by E.K.M. Tisdall, J.M. Davis and M. Gallagher, 11-28. London: SAGE Publications Ltd.

Gard, M. 2008. Producing Little Decision Makers and Goal Setters in the Age of the Obesity Crisis. Quest 60: 488-502.

Gard, M., and J. Wright. 2001. Managing Uncertainty: Obesity Discourses and Physical Education in a Risk Society. Studies in Philosophy and Education 20: 535-549.

Gard, M., and J. Wright. 2005. The Obesity Epidemic: Science, Morality and Ideology. Abingdon: Routledge.

Grant, B. 1997. Disciplining Students: The Construction of Student Subjectivities. British Journal of Sociology of Education 18(1): 101-114

Harwood, V. 2009. Theorizing Biopedagogies. In Biopolitics and the 'Obesity Epidemic': Governing Bodies, edited by J. Wright and V. Harwood, 1530. Abingdon: Routledge.

Johns, D.P. 2005. Recontextualising and Delivering the Biomedical Model as a Physical Education Curriculum. Sport, Education and Society 10 (1): 69-84.

LTS. 2004. A Curriculum Framework for Children 3-5. Accessed September 182009. http://www.ltscotland.org.uk/Images/CF3to5_tcm4-115469.pdf

LTS. 2009. Curriculum for Excellence. Accessed July 282011. http://www.ltscotland.org.uk/Images/all_experiences_outcomes_tcm4539562.pdf

Lupton, D. 1999. 'Developing the "whole me"": Citizenship, Neo-liberalism and the Contemporary Health and Physical Education Curriculum. Critical Public Health 9 (4): 287-300.

Macdonald, D. 2011. Like a Fish in Water: Physical Education Policy and Practice in the Era of Neoliberal Globalization. Quest 63: 36-45.

Macdonald, D., S. Rodger, R. Abbott, J. Ziviani, and J. Jones. 2005. 'I could do with a pair of wings': Perspectives on Physical Activity, Bodies and Health from Young Australian Children. Sport, Education and Society 10 (2): 195209.

MacLure, M. 2003. Discourse in Educational and Social Research. Buckingham: Open University Press.

McEvilly, N., M. Atencio, M. Verheul, and M. Jess. In press. Understanding the Rationale for Preschool Physical Education: Implications for Practitioners' and Children's Embodied Practices and Subjectivity Formation. Sport, Education and Society.

O’Flynn, G.H. 2004. Young Women's Meanings of Health and Physical Activity: The Body, Schooling, and the Discursive Constitution of Gendered and Classed Subjectivities. PhD diss., University of Wollongong.

O'Flynn, G. 2010. The Business of 'Bettering' Students' Lives: Physical and Health Education and the Production of Social Class Subjectivities. Sport, Education and Society 15 (4): 431-445.

O’Flynn, G. 2012. One Day I Sent Cake to My Children's Day Care. The Cake Came Home: Policing the New Health Imperatives in Preschools. Paper presented at the joint Australian Association for Research in Education and Asia-Pacific Educational Research Association Conference, Sydney, December 2-6. 
O'Flynn, G., and E.B. Petersen. 2007. The 'Good Life' and the 'Rich Portfolio': Young Women, Schooling and Neoliberal Subjectification. British Journal of Sociology of Education 28 (4): 459-472.

Quennerstedt, M. 2008. Exploring the Relation between Physical Activity and Health - A Salutogenic Approach to Physical Education. Sport, Education and Society 13 (3): 267-283.

Rønholt, H. 2002. 'It's Only the Sissies...': Analysis of Teaching and Learning Processes in Physical Education: A Contribution to the Hidden Curriculum. Sport, Education and Society 7 (1): 25-36.

The City of Edinburgh Council. 2013. Pre-school Nursery Education. Accessed January 232013.

http://www.edinburgh.gov.uk/info/851/nurseries_and_playgroups/566/preschool_nursery_education/1

Vander Schee, C. 2009. Confessions of the 'Unhealthy' - Eating Chocolate in the Halls and Smoking Behind the Bus Garage: Teachers as Health Missionaries. British Journal of Sociology of Education 30 (4): 407-419.

Vander Schee, C.J., and D. Boyles. 2010. 'Exergaming,' Corporate Interests and the Crisis Discourse of Childhood Obesity. Sport, Education and Society 15 (2): 169-185.

Wright, J. 2004. Post-structural Methodologies: The Body, Schooling and Health. In Body Knowledge and Control: Studies in the Sociology of Physical Education and Health, edited by J. Evans, B. Davies and J. Wright, 19-31. London: Routledge.

Wright, J., and R. Dean. 2007. A Balancing Act: Problematising Prescriptions About Food and Weight in School Health Texts. Utbildning \& Demokrati (Journal of Didactics and Educational Policy) 16 (2): 75-94.

Wright, J., and D. Macdonald. 2010. Young People, Physical Activity and the Everyday: The Life Activity Project. In Young People, Physical Activity and the Everyday, edited by J. Wright and D. Macdonald, 1-11. Abingdon: Routledge.

Wright, J., G. O'Flynn, and D. Macdonald. 2006. Being Fit and Looking Healthy: Young Women's and Men's Constructions of Health and Fitness. Sex Roles 54: 707-716.

Yelland, N., and A. Kilderry. 2008. Postmodernism, Passion and Potential for Future Childhoods. In Critical Issues in Early Childhood Education, edited by N. Yelland, 243-248. Maidenhead, Berkshire: Open University Press. 
Table 1. Oakdale, Cheery Faces and Sunnyland - demographic information.

\begin{tabular}{|c|c|c|c|c|c|}
\hline & Type of setting & $\begin{array}{l}\text { Location/ } \\
\text { SES }\end{array}$ & $\begin{array}{c}\text { Age of } \\
\text { children }\end{array}$ & $\begin{array}{c}\text { Number of } \\
\text { children }\end{array}$ & $\begin{array}{c}\text { Number of } \\
\text { practitioners }\end{array}$ \\
\hline Oakdale & $\begin{array}{l}\text { Attached to } \\
\text { primary school } \\
\text { (run by city } \\
\text { council) }\end{array}$ & $\begin{array}{c}\text { Urban } \\
\text { (low SES) }\end{array}$ & $\begin{array}{l}3-5 \\
\text { years }\end{array}$ & $\begin{array}{c}20 \text { in each of } \\
\text { two } \\
\text { preschool } \\
\text { classes }\end{array}$ & $\begin{array}{l}2 \text { (plus learning } \\
\text { assistant and } \\
\text { physical } \\
\text { education } \\
\text { teacher) }\end{array}$ \\
\hline $\begin{array}{l}\text { Cheery } \\
\text { Faces }\end{array}$ & $\begin{array}{l}\text { Partner-provider } \\
\text { (private; } \\
\text { preschool } \\
\text { education in } \\
\text { partnership with } \\
\text { city council) }\end{array}$ & $\begin{array}{l}\text { Suburban } \\
\text { (upper/ } \\
\text { middle } \\
\text { class) }\end{array}$ & $\begin{array}{c}6 \text { months } \\
-5^{1 / 2} \\
\text { years }\end{array}$ & $\begin{array}{c}75 \text { at a time } \\
\text { (130 on roll; } \\
35 \\
\text { preschoolers) }\end{array}$ & $\begin{array}{l}22(5 \text { in } \\
\text { preschool } \\
\text { rooms) }\end{array}$ \\
\hline $\begin{array}{c}\text { Sunny- } \\
\text { land }\end{array}$ & $\begin{array}{l}\text { Partner-provider } \\
\text { (owned by a } \\
\text { university; } \\
\text { preschool } \\
\text { education in } \\
\text { partnership with } \\
\text { city council) }\end{array}$ & $\begin{array}{l}\text { Urban } \\
\text { (mixed } \\
\text { SES, } \\
\text { mainly } \\
\text { middle } \\
\text { class) }\end{array}$ & $\begin{array}{c}21 / 2-5 \\
\text { years }\end{array}$ & $\begin{array}{l}24 \text { at a time } \\
\text { (37 on roll) }\end{array}$ & 5 \\
\hline
\end{tabular}

